\title{
TĖVŲ, AUGINANČIUU ONKOLOGINE LIGA SERGANČIUS VAIKUS, POTRAUMINIO STRESO SIMPTOMAI: SISTEMINĖ LITERATŪROS APŽVALGA
}

\author{
Irina Banienè, Nida Žemaitienè \\ Lietuvos sveikatos mokslu universitetas
}

Raktažodžiai: potrauminio streso simptomai, tèvai, onkologinèmis ligomis sergantys vaikai.

\section{Santrauka}

Vaiko vėžio diagnozè - tai vienas stipriausių, labiausiai gniuždančių ir paveikiančių išgyvenimų, kuriuos gali patirti tèvai. Manoma, jog žinia, kad vaikas serga gyvybei pavojinga liga yra laikomas ịvykiu, galinčiu sukelti sutrikimą - potrauminị stresą (ang. Posttraumatic stress disorder) (PTSD) ar iššaukti potrauminio streso simptomus (ang. Posttraumatic stress symptoms) (PTSS). Tyrimo tikslas: atrinkti ir apžvelgti publikacijas, kuriose buvo atliekamas potrauminio streso sutrikimui būdingų simptomų ịvertinimas tarp onkologine liga sergančius vaikus auginančių tėvų bei atskleisti PTSD ịvertinimui naudojamų metodų, PTSD rizikos veiksnių ir jų paplitimo ypatumus tarp onkologine liga sergančius vaikus auginančių tèvų. Metodika: sisteminè literatūros apžvalga atlikta EBSCO HOST: PsycARTICLES ir PubMed mokslinès literatūros duomenu bazèse. Rezultatai: nustatytus kriterijus atitiko ir ị sisteminę apžvalgą buvo įtraukti 14 straipsnių. I sisteminę analizę ịtrauktuose straipsniuose potrauminio streso simptomai daugiausia vertinami naudojant I̦vykio poveikio skalę (IES-R) ir PTSD kontrolinį sąrašą - Civilinę versiją (PCL-C). Nepaisant to, kad daugelyje straipsnių pabréžiama ilgalaikių tyrimų nauda, dauguma PTSD išsivystymo riziką paaiškinančių modelių yra grindžiami vienmomentiniais epidemiologiniais stebejjimo tyrimais. Sisteminè mokslinès literatūros apžvalgos analizė parodè, kad su PTSD išsivystymo rizika onkologine liga sergančių vaikų tėvams siejamų veiksnių spektras yra labai platus. PTSD išsivystymo rizika siejama su sociodemografiniais veiksniais, vaikams taikyto gydymo ypatumais, vaikų emocine būsena, tèvų ir vaikų sąveika, ankstesne tẻvų traumine patirtimi bei jų naudotomis streso ịveikos strategijomis ir daugeliu kitų. Apžvalga parodè, kad analizuojant su PTSD rizika siejamus veiksnius, svarbu atsižvelgti ir ị kultūrini kontekstą. Todèl ieškant veiksmingu PTSD prevencijos ir pagalbos tèvams būdų, reikalingi ị šalies sveikatos priežiūros ypatumus bei sociokultūrinį kontekstą orientuoti rizikos ir apsaugančiu veiksnių tyrimai.

\section{Ivadas}

Ivairūs gyvenimo sunkumai ir iššūkiai yra universali ir neišvengiama žmogiškojo gyvenimo dalis. Tačiau kai kurie ìvykiai gali būti ypač sukrečiantys ir stipriai paveikiantys asmens psichikos sveikatą, jo funkcionavimo ir prisitaikymo aplinkoje galimybes. Tai vadinamieji trauminiai ịvykiai. Tarptautinejje ligų klasifikacijoje (TLK-10) trauminis patyrimas yra apibūdinamas kaip įvykis ar situacija, ypač pavojinga arba katastrofiška, sukelianti stiprų distresą beveik kiekvienam. Unikalus, individualus ypatingos situacijos išgyvenimas, kurioje asmuo nebepajègia integruoti emocinio patyrimo arba patiriama grèsmè gyvybei, kūno vientisumui ir sveikatai, vadinamas trauma [24]. Traumų psichologijos srityje atliekami tyrimai rodo, kad dauguma žmonių bent kartą gyvenime yra susidūrę su trauminiais ìvykiais [23].

Kadangi psichologines traumas sukelia kraštutinio streso situacijos, jų pasekmès yra daug žalingesnès už streso pasekmes. Vaiko onkologinès ligos diagnozè yra vienas stipriausių, labiausiai paveikiančių ir gniuždančių išgyvenimų, kuriuos gali patirti tèvai. Žinia, kad vaikas serga gyvybei pavojinga liga, yra laikoma ịvykiu, galinčiu sukelti sutrikimą - potrauminį stresą ar potrauminio streso simptomus $[15,25,26]$. Iš kitos pusès, nereikètų pamiršti, kad žmogus turi daug galimybių ir gebejjimų sėkmingai ịveikti traumą ir išvengti jos žalojančių pasekmių. Tyrimai rodo, ne visi tą pati traumuojantị vaiko onkologinès ligos sukeltą įvykị išgyvenę tèvai patiria potrauminio streso simptomus. Manoma, kad yra specifinių veiksnių, kurie didina 
1 lentelè. Literatūros šaltinių ịtraukimo ir atmetimo kriterijai

\begin{tabular}{|c|c|c|}
\hline Kriterijus & İtraukimo kriterijus & Atmetimo kriterijus \\
\hline Laikotarpis & 2009.01.01.-2015.04.01. & $\begin{array}{l}\text { Anksčiau paskelbti } \\
\text { straipsniai }\end{array}$ \\
\hline Kalba & Anglų kalba & Kitos kalbos \\
\hline Tyrimo vieta & Visos pasaulio šalys & - \\
\hline Tyrimų tipai & $\begin{array}{l}\text { Stebejjimo analitiniai } \\
\text { tyrimai: koreliaciniai, } \\
\text { momentiniai, atvejo ir } \\
\text { kontrolès, kohortiniai }\end{array}$ & $\begin{array}{l}\text { Kokybiniai tyrimai } \\
\text { Kitokie nei stebèjimo } \\
\text { analitiniai tyrimai }\end{array}$ \\
\hline $\begin{array}{l}\text { Tyrimo } \\
\text { dalyviai }\end{array}$ & $\begin{array}{l}\text { Tèvai, slaugantys } \\
\text { ịvairių lokalizacijų } \\
\text { onkologine liga sergančius } \\
\text { nepilnamečius vaikus }\end{array}$ & $\begin{array}{l}\text { Kiti asmenys, } \\
\text { slaugantys ịvairių } \\
\text { lokalizacijų } \\
\text { onkologine liga } \\
\text { sergančius vaikus } \\
\text { Tẻvai, slaugantys } \\
\text { kitomis ligomis } \\
\text { sergančius vaikus. }\end{array}$ \\
\hline $\begin{array}{l}\text { Analizuojami } \\
\text { veiksniai } \\
\end{array}$ & PTSD, PTSS & $\begin{array}{l}\text { Nèra analizuojami } \\
\text { PTSD, PTSS }\end{array}$ \\
\hline $\begin{array}{l}\text { Publikacijų } \\
\text { prieinamumas }\end{array}$ & $\begin{array}{l}\text { Atvira prieiga iš LSMU } \\
\text { kompiuterių tinklo }\end{array}$ & $\begin{array}{l}\text { Ribota prieiga iš } \\
\text { LSMU tinklo }\end{array}$ \\
\hline
\end{tabular}

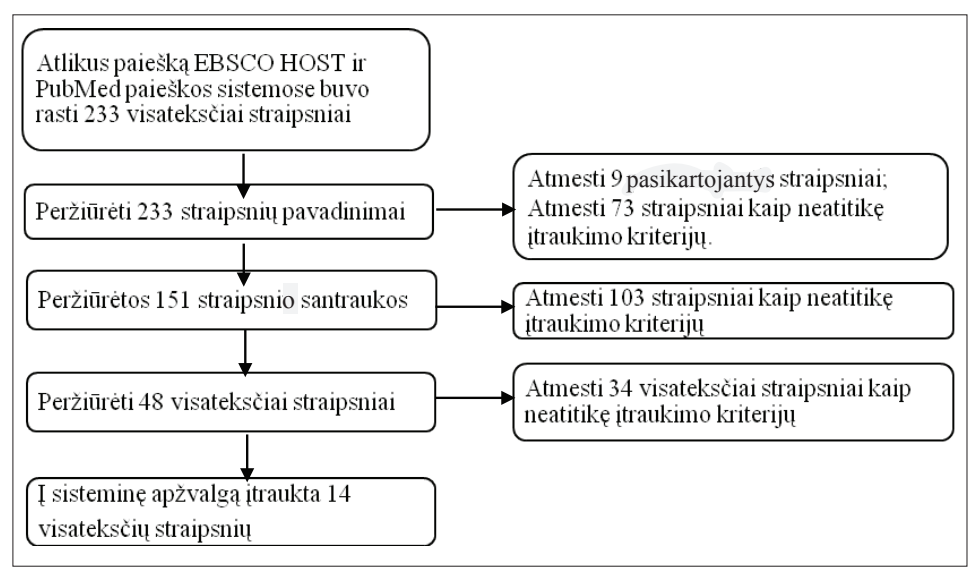

1 pav. Sisteminès literatūros šaltinių paieškos ir atrankos schema

pažeidžiamumą arba atsparumą traumai. Su traumos poveikiu asmeniui siejami veiksniai gali būti skirstomi ị veiksnius, egzistavusius iki traumos (pvz., genetinè predispozicija), veikiančius paties ịvykio metu (pvz., įvykio sunkumas ir trukmè) ir veikiančius po įvykio (pvz., socialinè parama) [18].

Apžvalgos tikslas: atrinkti ir išanalizuoti mokslines publikacijas, kuriose pristatomi rezultatai apie potrauminiam stresui būdingų simp- tomų paplitimą ir ypatumus tarp tėvų, auginančių onkologine liga sergančius vaikus. Uždaviniai: atskleisti PTSD įvertinimui naudojamų metodų, PTSD rizikos veiksnių ir jų paplitimo ypatumus tarp onkologine liga sergančius vaikus auginančių tèvų.

\section{Tyrimo metodai ir medžiaga}

Sisteminè literatūros paieška atlikta 2015-0401, naudojant EBSCO HOST: PsycARTICLES ir PubMed duomenų bazių paieškos sistemas. Paieškai atlikti pasitelkti šie raktažodžiai ir jų deriniai: PTSS or posttraumatic stress disoder symptoms and parents of children with cancer or mothers of children with cancer, su apribojimu Full text. Literatūros šaltinių įtraukimo ir atmetimo kriterijai pateikiami 1 lentelèje.

Atlikus paiešką EBSCO HOST ir PubMed paieškos sistemose buvo rasti 233 visateksčiai straipsniai. Visi literatūros šaltiniai, kuriuose nebuvo aprašomi tèvų, slaugančių onkologine liga sergančius vaikus, PTSD ar PTSS, buvo atmesti. Taip pat buvo atmesti tie šaltiniai, kuriuose buvo analizuojami kokybinių tyrimų rezultatai ar tam tikrų intervencijų efektyvumo vertinimai. Sisteminès literatūros šaltinių paieškos ir atrankos schema pateikta 1 paveiksle.

Nustatytus kriterijus atitiko ir ị sisteminę apžvalgą buvo ịtraukti 14 straipsnių, kuriuose buvo analizuojami tėvų, slaugančių onkologine liga sergančius vaikus, sutrikimas - potrauminis stresas, potrauminio streso simptomai, aprašomi ju ịvertinimo metodai bei rizikos veiksniai.

\section{Rezultatai}

Potrauminio streso ir potrauminio streso simptomų ịvertinimo metodai. İ sisteminę analizę pagal nustatytus duomenų ịtraukimo kriterijus pateko 14 straipsnių. 2 lentelèje pateikiamos pagrindinės tyrimų charakteristikos.

I sisteminę analizę ịtrauktuose straipsniuose tèvų, auginančių onkologine liga sergančius vaikus, sutrikimas - potrauminis stresas ar potrauminio streso simptomai daugiausia vertinami naudojant Itvykio poveikio skalę (ang. Impact of Events Scale, Revised) (IES-R) (iš 14 straipsnių 6: Nr.: 1, 2, 4, 5, 10, 11).

Kitas, keturiuose tyrimuose naudotas potrauminio streso vertinimo metodas - PTSD kontrolinis sąrašas - civiliams skirta versija (ang. PTSD 
2 lentelè. Potrauminio streso simptomų vertinimo metodikų charakteristikos

\begin{tabular}{|c|c|c|c|c|}
\hline Nr. & Autoriai, metai & Imtis & Tyrimo tipas & $\begin{array}{c}\text { PTSD ir/ar PTSS ịvertinimo } \\
\text { metodikos. } \\
\text { Metodikų patikimumas }\end{array}$ \\
\hline 1 & $\begin{array}{l}\text { N.Jurbergs, } \\
\text { A.Long, L.Ticona, } \\
\text { S.Phipps, } 2009\end{array}$ & $\begin{array}{l}\text { Onkologine liga sergančių } \\
\text { vaikų tėvai }(\mathrm{n}=199) \text { ( } 95 \\
\text { motinos, } 104 \text { tėvai). Sveikų } \\
\text { vaikų tėvai }(\mathrm{n}=108)\end{array}$ & $\begin{array}{l}\text { Momentinis tyrimas su kontroline } \\
\text { grupe }\end{array}$ & $\begin{array}{l}\text { Ivykio poveikio skalè (ang. } \\
\text { Impact of Events Scale, Revised) } \\
\text { (IES-R) (Horowitz et al., } \\
\text { 1979) (Weiss, Marmar, 1997). } \\
\text { Kronbach'o } \alpha=0,948\end{array}$ \\
\hline 2 & $\begin{array}{l}\text { G.L.Davis, } \\
\text { G.R.Parra, } \\
\text { S.Phipps, } 2010\end{array}$ & $\begin{array}{l}\text { Onkologine liga sergančių } \\
\text { vaikų tèvai ( } \mathrm{n}=193)(160 \\
\text { motinos, } 33 \text { tėvai) }\end{array}$ & Momentinis tyrimas & $\begin{array}{l}\text { Ivykio poveikio skalè (ang. } \\
\text { Impact of Events Scale, Revised) } \\
\text { (IES-R) (Horowitz et al., } \\
\text { 1979) (Weiss, Marmar, 1997). } \\
\text { Kronbach'o } \alpha=0,95 .\end{array}$ \\
\hline 3 & $\begin{array}{l}\text { A.L.Norberg, } \\
\text { U.Pöder, L.Essen, } \\
2011 .\end{array}$ & $\begin{array}{l}\text { Onkologine liga sergančių } \\
\text { vaikų tevvai }(\mathrm{n}=220) \text { (111 } \\
\text { motinos, } 109 \text { tėvai). }\end{array}$ & $\begin{array}{l}\text { Ilgalaikis tyrimas Vertinimai atlikti: } \\
\text { (T1) } 1 \text { sav. } \\
\text { (T2) } 2 \text { mèn. } \\
\text { (T3) } 4 \text { mėn. po diagnozės } \\
\text { sužinojimo. } \\
\text { (T4) } 1 \text { sv.po transplantacijos, } \\
\text { (T5) } 3 \text { mèn. ir } \\
\text { (T6) } 1 \text { metai po sėkmingo gydymo } \\
\text { ar vaiko mirties. }\end{array}$ & $\begin{array}{l}\text { PTSD kontrolinis sąrašas Civilinis } \\
\text { versija (ang. PTSD Checklist } \\
\text { Civilian Version) (PCL-C) } \\
\text { (Weathers et al., 1993). } \\
\text { Kronbach'o } \alpha=0,94\end{array}$ \\
\hline 4 & $\begin{array}{l}\text { M.Bruce, D. } \\
\text { Gumley, L.Isham, } \\
\text { P.Fearon, } \\
\text { K.Phipps, } 2011 .\end{array}$ & $\begin{array}{l}\text { CNS navikais sergančių vaiku } \\
\text { tèvai }(\mathrm{n}=52)(46 \text { motinos, } 6 \\
\text { tėvai) }\end{array}$ & Momentinis tyrimas & $\begin{array}{l}\text { Ivykio poveikio skalè (ang. } \\
\text { Impact of Events Scale, Revised) } \\
\text { (IES-R) (Horowitz et al., } \\
\text { 1979) (Weiss, Marmar, 1997). } \\
\text { Kronbach'o } \alpha=0,948 .\end{array}$ \\
\hline 5 & $\begin{array}{l}\text { M.J.Dunn et al., } \\
2012\end{array}$ & $\begin{array}{l}\text { Onkologine liga sergančių } \\
\text { vaiku tèvai ( } \mathrm{n}=283)(190 \\
\text { motinos, } 93 \text { tèvai) }\end{array}$ & Momentinis tyrimas & $\begin{array}{l}\text { İvykio poveikio skalè (ang. } \\
\text { Impact of Events Scale, Revised) } \\
\text { (IES-R) (Horowitz et al., } \\
\text { 1979) (Weiss, Marmar, 1997). } \\
\text { Kronbach'o } \alpha \alpha=0,93\end{array}$ \\
\hline 6 & $\begin{array}{l}\text { A.L.Norberg, } \\
\text { U.Pöder, } \\
\text { G.Ljungman, } \\
\text { L.Essen, } 2012\end{array}$ & $\begin{array}{l}\text { Onkologine liga sergančių } \\
\text { vaikų tèvai }(n=224)\end{array}$ & $\begin{array}{l}\text { Ilgalaikis tyrimas Vertinimai atlikti: } \\
\text { (T1) } 1 \text { sav. } \\
\text { (T2) } 2 \text { mėn. } \\
\text { (T3) } 4 \text { mėn. po diagnozės } \\
\text { sužinojimo. } \\
\text { (T4) } 1 \text { sv.po transplantacijos, } \\
\text { (T5) } 3 \text { mèn. ir } \\
\text { (T6) } 1 \text { metai po sėkmingo gydymo } \\
\text { ar vaiko mirties. }\end{array}$ & $\begin{array}{l}\text { PTSD kontrolinis sąrašas Civilinis } \\
\text { versija (ang. PTSD Checklist } \\
\text { Civilian Version) (PCL-C) } \\
\text { (Weathers et al., 1993). } \\
\text { Kronbach'o } \alpha=0,94\end{array}$ \\
\hline 7 & $\begin{array}{l}\text { M.Naderi, } \\
\text { M.F.Moghadam, } \\
\text { M.Hamzenejad, } \\
\text { A.Emamdadi, } \\
\text { H.Karami, 2012 }\end{array}$ & $\begin{array}{l}\text { Onkologine liga sergančių } \\
\text { vaikų tèvai }(\mathrm{n}=256)(128 \\
\text { motinos, } 128 \text { tèvai) }\end{array}$ & Momentinis tyrimas & $\begin{array}{l}\text { Potrauminio streso klausimynas } \\
\text { sudarytas pagal DSM-IV-TR } \\
\text { Kronbach'o } \alpha \text { nèra pateiktas. }\end{array}$ \\
\hline 8 & $\begin{array}{l}\text { M.A.Landolt, } \\
\text { E.Ystrom, } \\
\text { F.H.Sennhauser, } \\
\text { H.E.Gnehm, } \\
\text { M.E.Vollrath, } \\
2012\end{array}$ & $\begin{array}{l}\text { Tèvai }(\mathrm{n}=460) \text { ( } 239 \text { motinos, } \\
221 \text { tèvai), kurių } 138 \text { vaikai } \\
\text { patyrè nelaimingą atsitikimą, } \\
72 \text { vaikai susirgo I tipo } \mathrm{CD} ; 77 \\
\text { vaikai susirgo vėžiu. }\end{array}$ & $\begin{array}{l}\text { Ilgalaikis tyrimas su kontroline } \\
\text { grupe } \\
\text { Vertinimai atlikti: } \\
\text { (T1) 5-6 sav.; } \\
\text { (T2) } 1 \text { metai po ịvykio/diagnozès }\end{array}$ & $\begin{array}{l}\text { Potraumine diagnostikos } \\
\text { skale (ang. Post-traumatic } \\
\text { Diagnostic Scale) (PDS) (Foa, } \\
\text { CashmanJaycox, \&Perry, } \\
\text { 1997;Griesel, Wessa, irFlor, } \\
\text { 2006). } \\
\text { Kronbach'o } \alpha=0,87-0,90\end{array}$ \\
\hline 9 & $\begin{array}{l}\text { M.C.McCarthy, } \\
\text { D.M. Ashley, } \\
\text { K.J.Lee, } \\
\text { V.A.Anderson, } \\
2012\end{array}$ & $\begin{array}{l}\text { Onkologine liga sergančių } \\
\text { vaikų tèvai }(\mathrm{n}=145)\end{array}$ & $\begin{array}{l}\text { Ilgalaikis tyrimas Vertinimai atlikti: } \\
\text { (T1) - } 1 \text { mèn.; } \\
\text { (T2) 6-8 mèn. po diagnozès } \\
\text { nustatymo. } \\
\text { Pastaba: PTSD T1 nevertinti. }\end{array}$ & $\begin{array}{l}\text { PTSD kontrolinis sąrašas Civilinis } \\
\text { versija (ang. PTSD Checklist } \\
\text { Civilian Version) (PCL-C) } \\
\text { (Weathers et al., 1993). } \\
\text { Kronbach'o } \alpha=0,93\end{array}$ \\
\hline
\end{tabular}




\begin{tabular}{|c|c|c|c|c|}
\hline 10 & $\begin{array}{l}\text { A.L. Norberg, } \\
\text { K.K.Boman, } 2013\end{array}$ & $\begin{array}{l}\text { Onkologine liga sergančių vaikų } \\
\text { tėvai }(\mathrm{n}=62) \text { ( } 36 \text { motinos, } 26 \\
\text { tėvai) }\end{array}$ & $\begin{array}{l}\text { Ilgalaikis tyrimas Vertinimai } \\
\text { atlikti: } \\
\text { T1- nuo } 2 \text { sav. iki } 8 \text { mèn., } \\
\text { vidutinis laikas } 3,5 \text { mèn., po } \\
\text { diagnozės nustatymo. } \\
\text { T2 - nuo } 1 \text { iki } 3 \text { metu po pirmo } \\
\text { (T1) matavimo, vidutinis laikas } \\
\text { 20,6 mèn. }\end{array}$ & $\begin{array}{l}\text { Ivykio poveikio skalè (ang. Impact } \\
\text { of Events Scale, Revised) (IES-R) } \\
\text { (Horowitz et al., 1979) (Weiss, } \\
\text { Marmar, 1997). Cronbacho } \alpha=0,93\end{array}$ \\
\hline 11 & $\begin{array}{l}\text { K.K.Boman, } \\
\text { Y.Kjallander, } \\
\text { S.Eksborg, } \\
\text { J.Becke, } 2013\end{array}$ & $\begin{array}{l}\text { Onkologine liga sergančių vaikų } \\
\text { tėvai }(\mathrm{n}=169) \text { ( } 97 \text { motinos, } 72 \\
\text { tėvai) }\end{array}$ & Momentinis tyrimas & $\begin{array}{l}\text { Ivykio poveikio skale (ang. Impact } \\
\text { of Events Scale, Revised) (IES-R) } \\
\text { (Horowitz et al., 1979) (Weiss, } \\
\text { Marmar, 1997). } \\
\text { Cronbacho } \alpha \text { nèra pateiktas. }\end{array}$ \\
\hline 12 & $\begin{array}{l}\text { L.Stoppelbein, } \\
\text { L.Greening, } \\
\text { H.Wells, } 2013\end{array}$ & $\begin{array}{l}\text { Onkologine liga sergančių vaikų } \\
\text { tévai }(\mathrm{n}=111) \text { ( } 104 \text { motinos, } 7 \\
\text { tėvai) }\end{array}$ & Momentinis tyrimas & $\begin{array}{l}\text { Potrauminio streso sutrikimo } \\
\text { reakcijos indekso skalè (ang. } \\
\text { Posttraumatic Stress Disorder- } \\
\text { Reaction Index) (PTSD-RI). } \\
\text { Cronbacho } \alpha=0,89\end{array}$ \\
\hline 13 & $\begin{array}{l}\text { M.Tremolada, } \\
\text { S.Bonichini, } \\
\text { D.Aloisio, } \\
\text { S.Schiavo, } \\
\text { M.Carli, } \\
\text { M.Pillon, } 2013\end{array}$ & $\begin{array}{l}\text { Leukemija sergančių vaikų } \\
\text { motinos }(\mathrm{n}=76)\end{array}$ & $\begin{array}{l}\text { Ilgalaikis tyrimas Vertinimai } \\
\text { atlikti: } \\
\text { (T1) } 1 \text { sav. } \\
\text { (T2) } 1 \text { mèn. } \\
\text { (T3) } 6 \text { mèn. } \\
\text { (T4) } 12 \text { mèn. } \\
\text { (T5) } 24 \text { mèn. po diagnozès } \\
\text { nustatymo. } \\
\text { Pastaba: PTSD T1 nevertinti. }\end{array}$ & $\begin{array}{l}\text { PTSD simptomų nustatymo } \\
\text { kontrolinis sąrašas (ang. PTSD } \\
\text { symptom checklist) (adapted version } \\
\text { of Manne et al., 1998). Cronbacho } \\
\alpha=0,72\end{array}$ \\
\hline 14 & $\begin{array}{l}\text { R.Riva, } \\
\text { U.Forinder, } \\
\text { J.Arvidson, } \\
\text { K.Mellgren, } \\
\text { J.Toporski, } \\
\text { J.Winiarski, } \\
\text { A.L.Norberg, } \\
\text { 2014 }\end{array}$ & $\begin{array}{l}\text { Vaikų, kuriems buvo atlikta } \\
\text { kaulų čiulpų transplantacija, tèvai } \\
(\mathrm{n}=260)(146 \text { motinos, } 114 \text { tèvai })\end{array}$ & Momentinis tyrimas & $\begin{array}{l}\text { PTSD kontrolinis sąrašas Civilinis } \\
\text { versija (ang. PTSD Checklist } \\
\text { Civilian Version) (PCL-C) } \\
\text { (Weathers et al., 1993). } \\
\text { Cronbacho } \alpha=0,94\end{array}$ \\
\hline
\end{tabular}

Checklist Civilian Version) (PCL-C) (iš 14 straipsnių 4: Nr.: $3,6,9,14)$. Visų analizuojamuose straipsniuose naudojamų metodikų tinkamumas buvo ịvertintas ir pripažintas tinka$\mathrm{mu}$ (Kronbach'o $\alpha>0,5)$. I sisteminę analizę įtrauktas vienas straipsnis (Nr.7), kuriame taip pat analizuojami tèvų, auginančių onkologine liga sergančius vaikus, potrauminio streso sutrikimo simptomai, aprašytoje tyrimo metodologijoje nurodoma, kad naudojamas standartinis potrauminio streso sutrikimo klausimynas, kuris remiasi DSM-IV-TR klasifikacija. Kronbach'o $\alpha$ nèra pateiktas.

Kaip matome iš antroje lenteleje pateiktų duomenų (2 lentelè), ị sisteminę analizę įtrauktuose straipsniuose tèvų, slaugančių onkologine liga sergančius vaikus, potrauminis stresas daugiausia vertinamas atliekant momentinius tyrimus (iš 14 straipsnių $8 \mathrm{Nr} .: 1,2,4,5,7,11,12,14$ ), jų metu atliekami vienkartiniai potrauminio streso simptomu ịvertinimai. Šešių tyrimų tipai - ilgalaikiai (Nr.3, 6, 8, 9, $10,13)$, atlikti du ir daugiau ivertinimai. Trys tyrimai truko 1 metus (Nr.3, 6, 8), iš jų dviejuose (Nr.3, 6) atlikti šeši ivertinimai, viename (Nr.8) - du. Viename tyrime (Nr.10) atlikti du ịvertinimai, pirmas nuo 2 sav. iki 8 mèn. (vidutinis laikas 3,5 mèn.) po diagnozès nustatymo, antras - nuo 1 iki 3 metu po pirmo įvertinimo (vidutinis laikas 20,6 mèn.). Kitame tyrime, trukusiame dvejus metus (Nr.10), atlikti du ivertinimai. Dar viename (Nr.9) atlikti du įvertinimai: 1 mèn. ir 6-8 mèn. po diagnozès nustatymo.

Dviejuose straipsniuose aprašytuose tyrimuose buvo kontrolinè grupé (Nr.1, 8). Viename tyrime (Nr.1) kontrolinę grupę sudarè sveikų vaikų tėvai, kitame (Nr.8) - tėvai, kurių vaikai patyre nelaimingą atsitikimą ir tèvai, kurių vaikai susirgo I tipo cukriniu diabetu (CD).

Potrauminio streso rizikos veiksniai ir jụ paplitimo ypatumai. Pagrindiniai potrauminio streso simptomai, kurie pasireiškia onkologine liga sergančių vaikų tèvams, tai ypač jautrus, skaudus vaiko diagnozès ir ligos išgyvenimas, emocijų slopinimas, pastovus dirglumas (Nr.10), nesugebejimas susitvarkyti su nemiga, ikyriomis mintimis, kognityvinių funkcijų silpnèjimas, su liga susijusių emocijų ir minčiu vengimas, savo jausmų slèpimas nuo kitų, padidèjęs jautrumas ir pyk- 
tis bei kiti psichologiniai ir emociniai sunkumai (Nr.5).

Siekiant atskleisti PTSD išsivystymo riziką, daugiau ar mažiau visose ị sisteminę analizę įtrauktuose tyrimuose buvo vertinami sociodemografiniai veiksniai. Vieni ị sisteminę apžvalgą įtrauktų tyrimų rezultatai rodo, kad tèvų PTSS nèra statistiškai reikšmingai susiję su tėvų lytimi (Nr.1, 5, 6). Vienas iš tyrimų parodè, kad tų pačių šeimų mamos ir téčiai patiria panašius PTSS, depresijos ir nerimo simptomus (Nr.5). Tačiau kiti tyrimai rodo, kad motinoms PTSS pasireiškia daugiau, nei tėvams (Nr.7, 8, 9, 11). Vieni autoriai nurodo, kad amžius ir imigrantų statusas neturejo reikšmingos įtakos PTSS pasireikšti (Nr.11), kai tuo tarpu kito tyrimo rezultatai parodè, kad kuo tèvų amžius yra jaunesnis, tuo potrauminio streso stiprumas yra didesnis (Nr.7), bedarbyste ir imigracija prognozuoja aukštesnius PTSS (Nr.6). Viename ị sisteminę analizę ịtrauktame tyrime buvo pateikti rezultatai, rodantys, kad tarp žemesnio išsilavinimo tèčių potrauminio streso simptomai yra stipriau išreikšti nei tarp tèčių su aukštesniu išsilavinimu (Nr.5). Tačiau kito tyrimo rezultatai parode, kad aukštesnio mokslo lygmens tèvai patiria stipriau išreikštus potrauminio streso simptomus, nei mažiau išsilavinę tèvai (Nr.7).

Be sociodemografinių veiksnių, tèvų PTSD, PTSS buvo vertinami atsižvelgiant ị vaikų ligą bei vaikams taikyto gydymo ypatumus (pvz. diagnozè, laikas nuo diagnozès nustatymo, transplantacija ir kt.) (Nr.: 1, 5, 6, 8, 9), vaiku potrauminio streso simptomų pasireiškimų $(\mathrm{Nr} .8,12)$, vaikų gyvenimo kokybės rodikliais (Nr.9), vaikų emociniais ir elgesio sunkumais bei pykčio reguliavimo ịgūdžiais (Nr.2).

Apžvelgiamų tyrimų rezultatai rodo, kad tèvų potrauminio streso simptomų pasireiškimas yra susijęs su vaiko sveikimo proceso ypatumais. Tẻvų, kurių vaikai patyré ligos atkryti, PTSS buvo stipriau išreikšti, nei tèvų, kurių vaikai gydėsi pirmą kartą (Nr.5). Tai patvirtina ir kito tyrimo rezultatai, kurie rodo, kad ligos atkrytis yra reikšmingas prognostinis veiksnys diagnozuojant tèvų PTSD (Nr.1). Tèvų suvokiamas vaikų psichologinis stresas, baimé, fiziniai simptomai (Nr.6), prasta vaiko gyvenimo kokybè (Nr.9) susiję su aukštesniais potrauminio streso simptomų rodikliais. Taip pat tėvu PTSD, PTSS buvo vertinami matuojant tèvų naudojamas streso įveikimo strategijas (Nr.3, 12), tẻvų emocinę būseną ir kognityvines funkcijas (Nr.5, 9, 13,14), trauminę patirtị (Nr.11), subjektyvų kontrolès jausmo praradimą (Nr.10) ir subjektyviai suvokiamą vaikų psichologinį stresą (Nr.6). Viename tyrime tèvų potrauminio streso simptomai buvo vertinami atsižvelgiant ị tèvų ir vaikų sąveiką (Nr.4), kitame - į šeimos funkcionavimą (Nr.9).

Viename iš analizuotų tyrimų buvo nustatyta, kad aukštesni tèvų potrauminio streso simptomai buvo susiję su aukštesniais vaikų potrauminio streso simptomais (Nr.8).
Taip pat, tèvų PTSS siejosi su vengimo ir ị savęs kaltinimą nukreiptomis streso ịveikos strategijomis bei narkotinių medžiagų ir alkoholio vartojimu. Tẻvų narkotinių medžiagų ir alkoholio vartojimas taip pat buvo reikšmingai susijęs su vaiku PTSS (Nr.12). Kitame tyrime (Nr.2), nustatyta, kad tèvų PTSS buvo tiesiogiai susiję su vaikų emociniais ir elgesio sunkumais. Didesnè tèvų potrauminio streso simptomatika susijusi su mažesniais vaikų pykčio reguliavimo igūdžiais, o sunkumai reguliuojant pyktị reikšmingai susiję su aukštesnio lygio vaikų emociniais ir elgesio sunkumais.

\section{Aptarimas}

Atlikto tyrimo duomenimis, viena iš plačiausiai taikomų PTSD ịvertinančių metodikų yra İvykio poveikio skalè (IES-R). Ši skalè naudojama tiek onkologinèmis ligomis sergančių vaikų tèvų PTSD rizikai, tiek ir potrauminio streso simptomams vertinti. IES-R yra originalios [17] metodikos, susidedančios iš pasikartojančių traumuojančio ìvykio išgyvenimų simptomų (invazijos) subskalès ir vengimo subskalès modifikacija. D.S.Weiss ir C.R.Marmar šią metodiką papildè pridèdami trečią subskalę, matuojančią padidintą dirglumą. IES-R pasižymi geromis psichometrinemis charakteristikomis. Metodika iš anglų kalbos yra išverta ị vokiečių, prancūzų, italų, olandų, japonų, kinų kalbas. IES-R skalè yra išversta ir adaptuota Lietuvoje 2005 metais [20].

Kai kurių autorių teigimu, pats sunkiausias onkologine liga sergančių vaikų tėvų išgyvenamas laikotarpis - pirmieji 6 mènesiai po ligos diagnozavimo [22]. Tai laikas, per kurị tèvai sužino apie vaiko véžio diagnozę, kartu su vaiku išgyvena daugybę tyrimų, pradeda sunkų ir varginanti gydymą. O visa tai gali turèti ilgalaikių pasekmių ir prisidèti prie potrauminio streso simptomų pasireiškimo. Todèl analizuojant PTSD išsivystymo riziką paaiškinančius veiksnius yra svarbu atlikti ilgalaikius tyrimus. Tačiau, atlikta analizè parodè, kad analizuojant tėvų, slaugančių onkologine liga sergančius vaikus, potrauminis stresas daugiausia vertinamas atliekant momentinius, o ne ilgalaikius tyrimus.

Analizuojant PTSD išsivystymo riziką tarp onkologine liga sergančius vaikus auginančių tèvų, daugiau ar mažiau visuose $\mathfrak{i}$ sisteminę analizę itrauktuose tyrimuose buvo vertinami sociodemografiniai rodikliai (tèvų lytis, amžius, išsilavinimas ir kt.). Tačiau analizè atskleidè daug prieštaringų rezultatų. Pavyzdžiui, analizuojant PTSD ir PTSS pasireiškimą pagal tèvų lytị, vieni autoriai nurodo, kad PTSS nèra statistiškai reikšmingai susiję su tèvų lytimi, kiti autoriai teigia, kad potrauminio streso simptomai dažniau pasireiškia mamoms nei teěiams. Nèra aišku, ar skirtumas tarp motinu ir tèvų šiuose tyrimuose nurodo skirtingas reakcijas ị vaikų vėži, ar jis susijęs su skirtumais bendrojoje 


\section{2}

gyventojų statistikoje. Moterys, atrodo, labiau linkusios kalbèti apie patiriamą diskomfortą, simptomus, sunkumus, nei vyrai. Todèl lyčiu skirtumai gali būti susiję su atsakinèjimo stiliumi. Dar vienas galimas paaiškinimas yra tas, kad motinoms dažniau tenka pagrindinè atsakomybè dèl vaiko priežiūros, kai tuo tarpu tèvai ị vaikų priežiūrą ịtraukiami epizodiškai [26]. Taigi, išlieka klausimas, ar nustatyti lyčių skirtumai yra prasmingi ir ar dèl to motinoms reikia daugiau psichikos sveikatos specialistų pagalbos nei tėvams, išlieka atviras.

Taip pat prieštaringi duomenys yra gaunami analizuojant potrauminio streso simptomų pasireiškimą atsižvelgiant ị tėvų išsilavinimą. Pastebèta, kad žemesnis išsilavinimas gali būti susijęs su stipriau išreikštais PTSS. Tai gali būti susiję su žemesnị išsilavinimą turinčių tėvų darbo ypatumais. Žemesnio išsilavinimo asmenų darbas gali būti mažiau apmokamas, jų darbo grafikas mažiau lankstus. Tai gali tapti papildomu stresoriumi, trukdančiu skirti pakankamai demesio tiek sergantiems, tiek ir sveikiems vaikams. O dèl šių priežasčių kylantis stresas kaupiasi ir didina PTSS stiprumą bei išreikštumą. Tačiau, kito tyrimo, atlikto Irane, autoriai nurodo, kad labiau išsilavinę tèvai patiria stipresnius PTSS, nei mažiau išsilavinę tevvai. Autoriai mano, kad tèvai su aukštuoju išsilavinimu turi daugiau supratimo apie savo vaiko ligą, kas gali turèti įtakos jų patiriamam psichologiniam stresui. Lygindami šiuos rezultatus, atliktus skirtingose kultūrose, galime daryti prielaidą, kad tai gali būti susiję ir su sociokultūrine aplinka.

Atlikta analizè parodè, kad tèvų potrauminio streso simptomų pasireiškimas yra susijęs ir su vaiko onkologinès ligos eiga. Pastebima, kad ligos atkrytis yra reikšmingas prognostinis PTSD veiksnys. Tai patvirtina ir anksčiau atliktų tyrimų rezultatai, kurie parodè, kad sunkesnè liga [21] arba recidyvas [19] susijęs su tèvų patiriamu didesniu stresu.

Analizuojant PTSD išsivystymo riziką, tyrejai atkreipia dèmesị ir ị tèvų naudojamas streso ịveikimo strategijas susidūrus su vaiko vėžio liga. Dauguma tyrimų, analizuojančių, kaip streso įveikimo būdai nulemia individo prisitaikymą prie aplinkos bei jo psichinius, emocinius ir somatinius sutrikimus, pabrežia, kad naudojamos streso įveikos yra svarbus kintamasis, lemiantis gerą individo savijautą [16]. Apžvelgus tyrimų rezultatus galime teigti, kad neadaptyvūs streso ịveikimo būdai (vengimas, alkoholio vartojimas, savęs kaltinimas ir kt.) gali būti PTSD rizikos veiksniai.

\section{Išvados}

1. I sisteminę analizę ịtrauktuose straipsniuose potrauminio streso simptomai daugiausia vertinami naudojant Itvykio poveikio skalę (IES-R) ir PTSD kontrolinį sąrašą
- Civilinę versiją (PCL-C). Nepaisant to, kad daugelyje straipsnių pabrèžiama ilgalaikių tyrimų nauda, dauguma PTSD išsivystymo riziką paaiškinančių modelių yra grindžiami vienmomentiniais epidemiologiniais stebejjimo tyrimais.

2. Su PTSD išsivystymo rizika onkologine liga sergančių vaikų tėvams siejamų veiksnių spektras yra labai platus. PTSD išsivystymo rizika siejama su sociodemografiniais veiksniais (lytis, amžius, išsilavinimas, bedarbyste, emigracija), vaikams taikyto gydymo ypatumais, vaiku emocine būsena, tėvų ir vaikų sąveika, ankstesne tèvų traumine patirtimi, naudojamomis streso ịveikos strategijomis ir daugeliu kitų.

3. Analizè parodè, kad analizuojant su PTSD rizika siejamus veiksnius, svarbu atsižvelgti ir ị kultūrinį kontekstą. Todèl ieškant veiksmingų PTSD prevencijos ir pagalbos tèvams būdų, reikalingi ị šalies sveikatos priežiūros ypatumus bei sociokultūrinį kontekstą orientuoti PTSD rizikos ir apsaugančių veiksnių tyrimai.

\section{Literatūra}

1. Jurbergs N, Long A, Ticona L, Phipps S. Symptoms of posttraumatic stress in parents of children with cancer: Are they elevated relative to parents of healthy children? J Pediatr Psychol 2009; 34(1):4-13.

2. Davis GL, Parra GR, Phipps S. Parental posttraumatic stress symptoms due to childhood cancer and child outcomes: investigation of the role of child anger regulation. Children's Health Care. 2010; 39:173-184.

3. Norberg AL., Pöder U, Essen L. Early avoidance of diseaseand treatment-related distress predicts post-traumatic stress in parents of children with cancer. European Journal of Oncology Nursing 2011; 15:80-84.

4. Bruce M, Gumley D, Isham L, Fearon P, Phipps K. Post-traumatic stress symptoms in childhood brain tumour survivors and their parents. Child Care Health Dev 2011; 37(2):244-51.

5. Dunn MJ, Rodriguez EM, Barnwell AS, Grossenbacher JC, Vannatta K, Gerhardt CA, Compas BE. Posttraumatic stress symptoms in parents of children with cancer within six months of diagnosis. Health Psychol 2012; 31(2):176-85.

6. Norberg AL., Pöder U, Ljungman G, Essen L. Objective and subjective factors as predictors of post-traumatic stress symptoms in parents of children with cancer - A Longitudinal Study. PlosOne 2012; 7(5).

7. Naderi M, Firouzkoohi Moghadam M, Hamzenejad M, Emamdadi A, Karami H. Post-traumatic stress disorder and related factors in parents of children with cancer in South-East of Iran. Iran Red Crescent Med J. 2012; 14(12):776-81.

8. Landolt MA, Ystrom E, Sennhauser FH, Gnehm HE, Vollrath ME. The mutual prospective influence of child and parental post-traumatic stress symptoms in pediatric patients. J Child Psychol Psychiatry 2012; 53(7):767-74. 
9. McCarthy MC, Ashley DM, Lee KJ, Anderson VA. Predictors of acute and posttraumatic stress symptoms in parents following their child's cancer diagnosis. J Trauma Stress 2012; 25(5):558-66.

10. Norberg AL, Boman KK. Mothers and fathers of children with cancer: loss of control during treatment and posttraumatic stress at later follow-up. Psychooncology 2013; 22(2):324-9.

11. Boman KK, Kjällander Y, Eksborg S, Becker J. Impact of prior traumatic life events on parental early stage reactions following a child's cancer. Published online 2013(14).

12. Stoppelbein L, Greening L, Wells H. Parental coping and posttraumatic stress symptoms among pediatric cancer populations: tests of competing models. Psychooncology 2013; 22(12):2815-22.

13. Tremolada M, Bonichini S, Aloisio D, Schiavo S, Carli M, Pillon M. Post-traumatic stress symptoms among mothers of children with leukemia undergoing treatment: a longitudinal study. Psychooncology 2013; 22(6):1266-1272.

14. Riva R, Forinder U, Arvidson J, Mellgren K, Toporski J, Winiarski J, Norberg AL. Patterns of psychological responses in parents of children that underwent stem cell transplantation. Psychooncology 2014; 23(11):1307-1313.

15. Kazak AE, Simms S, Alderfer MA, Rourke MT, Crump T, McClure K. et al. Feasibility and preliminary outcomes from a pilot study of a brief psychological intervention for families of children newly diagnosed with cancer. J Pediatr Psychol 2005; 30(8):644-655.

16. Domanskaitè-Gota V. Lietuvos ir Danijos paauglių psichologinio traumatizmo ypatumai. Magistro darbas. Vilnius: Vilniaus universitetas, 2000.

17. Horowitz M,Wilner N, Alvarez W. Impact of event scale: a measure of subjective stress. Psychosomatic Medicine 1979; 41(3):181-271.

18. Yehuda R. Risk and resilience in posttraumatic stress disorder. J Clin Psychiatry.2004; 65(1):29-36.

19. Jurbergs N, Long A, Ticona L, Phipps S. Symptoms of posttraumatic stress in parents of children with cancer: are they elevated relative to parents of healthy children? Journal of Pediatric Psychology 2009; 34: 4-13.

20. Kazlauskas E., Gailienè D., Domanskaitė-Gota V.,Trofimova J. İvykio poveikio skalès - revizuotos (IES-R).Lietuviškos versijos psichometrinès savybès. Psichologija, 2006; 33:22-30.

21. Magal-Vardi O, Laor N, Toren A, Strauss L, Wolmer L, Bielorai B et al. Psychiatric morbidity and quality of life in children with malignancies and their parents. J Nerv Ment Dis 2004; 192(12):872-875.

22. Makari J. Lietuvos vaikų, sergančių onkologinėmis ligomis, gyvenimo kokybè. Daktaro disertacija, 2008.

23. Naujokaitė A., Želvienė P. Trauminès ir stresinès patirties sąsajos su psichologine gerove. Jaunųjų mokslininkų psichologų darbai. 2014; 3 .
24. Pearlman LA, Saakvitne K. Helpers' responses to trauma work: Understanding and intervening in an organization. Lutherville, MD: Sedran Press 1995.

25. Pöder U, Ljungman G. Posttraumatic stress disorder among parents of children on cancer treatment: a longitudinal study. Psycho-Oncology 2008; 17 (5):430-437.

26. Vrijmoet-Wiersma, C. M. J., Van Klink, J. M. M., Kolk, A. M., Koopman, H. M., Ball, L. M., \& Egeler, R. M. Assessment of parental psychological stress in pediatric cancer: A review. Journal of Pediatric Psychology 2008; 33(7): 694-706.

\section{THE POST-TRAUMATIC STRESS SYMPTOMS IN PARENTS OF PEDIATRIC PATIENTS WITH ONCOLOGICAL DISEASES: A SYSTEMATIC REVIEW}

\section{Banienė, N. Žemaitienè}

Key words: post-traumatic stress symptoms, parents, pediatric patients with oncological diseases.

Summary

Diagnosis of childhood cancer is one of the strongest, most devastating and affecting experiences taken into consideration by parents. It is commonly accepted that a message about a child's life-threatening disease might develop a post-traumatic stress disorder (PTSD) or post-traumatic stress symptoms (PTSS). The aim of the research: to select and review publications related with post-traumatic stress symptoms, which affect parents, who have children with oncological diseases. Methodology: a systematic review. Results: the systematic review revealed the variety of valuation techniques used in scientific researches. The articles included in the systematic analysis show that post-traumatic stress symptoms are mostly evaluated according to the impact of event scale (IES-R) and PTSD checklist - civil version (PCL-C). Despite the benefits of longitudinal researches mentioned in many articles, many models are still based on the instantaneous tracking study. As per results of the systematic review, there is a wide range of factors that can affect the development of post-traumatic stress symptoms in parents who have children with oncological diseases. These are socio-demographic factors associated with the specifics of treatment, emotional state of children, traumatic experience and the coping strategies of parents, relationship between parents and children, etc. The cultural context is also important when analysing factors that might affect the development of PTSS. In order to help the parents who have children with oncological diseases function better, it is crucial to study the post-traumatic stress symptoms that occur as well as predisposed and protecting factors.

Correspondence to: baniene.irina@gmail.com

Gauta 2015-05-13 